\title{
PREDIKSI DAMPAK COVID-19 TERHADAP PENDAPATAN NELAYAN JARING INSANG DI KOTA BENGKULU
}

Prediction of COVID-19 Impact on Gillnet Fishermen in Bengkulu City

\author{
Oleh: \\ Muhammad Natsir Kholis ${ }^{1}$, Fraternesi ${ }^{2}$, La Ode Wahidin ${ }^{3}$ \\ ${ }^{1}$ Jurusan Pemanfaatan Sumberdaya Perikanan Fakultas Perikanan, Universitas Muara \\ Bungo-Jambi, Indonesia \\ ${ }^{2} J u r u s a n$ Akuntansi Fakultas Ekonomi Universitas Muhammadiyah Bengkulu, Indonesia \\ ${ }^{3} J u r u s a n$ Ilmu Perikanan Fakultas Pertanian, Universitas Bina Insan-Lubuk Linggau \\ Sumatera Selatan, Indonesia \\ Korespondensi: kholis2336@gmail.com
}

\begin{abstract}
ABSTRAK
Fluktuasi pendapatan nelayan memiliki banyak faktor, ada yang dapat dikendalikan dan ada faktor yang tidak dapat dikendalikan. Salah satu faktor yang diyakini mempengaruhi pendapatan nelayan yaitu pandemi COVID-19. Penelitian dilaksanakan pada Bulan April-Mei 2020 di Kota Bengkulu. Tujuan penelitian ini yaitu untuk memprediksi dampak COVID-19 terhadap pendapatan nelayan jaring insang di Kota Bengkulu. Metode yang digunakan yaitu metode studi kasus dengan menggunakan analisis tren (time series). Hasil penelitian menunjukkan total pendapatan nelayan jaring insang di Kota Bengkulu memiliki garis persamaan $\hat{Y}=1.899 .371$-358562.86 (x). Persamaan tersebut memprediksi tren pendapatan nelayan jaring insang di Kota Bengkulu akan menurun tajam hingga bulan Desember 2020. Dampak dari pandemi COVID-19 sangat dirasakan nelayan akibat turunnya harga penjualan ikan. Nelayan jaring insang diprediksi akan berhutang mulai Bulan Juli 2020 sampai Bulan Desember 2020, dengan prediksi puncak penurunan pendapatan tertinggi dan awal berhutang pada Bulan Juli 2020 dengan persentase sebesar $-336 \%$.
\end{abstract}

Kata kunci: Bengkulu, COVID-19, Jaring Insang, Pendapatan

\section{ABSTRACT}

Fluctuation in fisherman income has many factors, some of which can be controlled and there are factors which cannot be controlled. One of the factors that take effect income fisherman is the pandemic COVID-19. The study was conducted in April to May 2020 in the Bengkulu City. The purpose of this study was to predict the impact of COVID-19 on gill net fishermen income in Bengkulu City. The method used is the case study method using trend analysis (time series). The results showed the total net income of fisherman in Bengkulu City had the equation $\hat{Y}=1,899,371-358562.86(x)$. This equation infers a sharp decline of fishermen income until the end of this year (December 2020). The impact of the COVID-19 pandemic influence highly decreasing the fish price locally. Gill net fisherman are predicted to be in debt from July 2020 to December 2020, with the highest predicted decline in income and the beginning of debt in July 2020 with a percentage of -336\%.

Key words: Bengkulu, COVID-19, Gill net, Income 


\section{PENDAHULUAN}

Letak geografis di pesisir barat Pulau Sumatera yang berhadapan dengan Samudera Indonesia menjadikan Kota Bengkulu memiliki potensi perikanan yang sangat besar (Mulyasari, 2015). Potensi sumberdaya ini meliputi dua kategori, yaitu sumberdaya perikanan laut di wilayah teritorial (0-12 mil laut) sebesar 46.145 ton/tahun dan di wilayah laut ZEEI (12-200 mil laut) sebesar 80.072 ton/tahun. Potensi jenis ikan laut yang ada terdiri dari ikan pelagis besar dan kecil, ikan demersal dan biota laut lainnya (Dirjen PDSPKP KKP, 2018). Sumberdaya perikanan di perairan telah dimanfaatkan oleh masyarakat setempat sebagai sumber mata pencaharian sejak lama (Erwina et al., 2015) yaitu menyokong mata pencaharian sebagian besar masyarakat pesisir sekaligus sebagai bahan makanan, sebagai sumber ekonomi pembangunan daerah dan sebagai sumber dukungan bagi kegiatan rekreasi masyarakat berupa pemancingan (Masydzulhak, 2005).

Kegiatan usaha penangkapan ikan di Kota Bengkulu meliputi nelayan kecil dengan teknologi yang masih sederhana (Mulyasari, 2015). Alat tangkap yang digunakan oleh sebagian besar nelayan di kota ini adalah jaring insang dengan berbagai ukuran sesuai dengan musim penangkapan. Jumlah alat tangkap jaring insang tercatat sebanyak 1.435 unit atau sekitar $47 \%$ dari jumlah total alat tangkap yang ada di kota ini (Data Statistik KKP, 2016); (Dirjen PDSPKP KKP, 2018). Kesejahteraan nelayan salah satunya ditentukan oleh adanya tingkat pendapatan nelayan. Pendapatan nelayan merupakan akumulasi dari hasil usaha nelayan yang tidak berdiri sendiri, namun dipengaruhi oleh berbagai faktor. Oleh karena itu, pendapatan nelayan di Kota Bengkulu mengalami fluktuasi seiring dengan fluktuasi faktor-faktor pendukungnya seperti permodalan, musim, iklim, produktivitas alat tangkap, daerah penangkapan ikan (Indara et al., 2017), harga ikan dan jumlah hasil tangkapan (Ridha, 2017).

Corona virus disease 2019 (COVID-19) pertama kali diidentifikasi pada Desember 2019 di Wuhan, Tiongkok, telah menyebabkan pandemi dan menimbulkan kepanikan masyarakat di seluruh dunia saat ini (Azamfirei, 2020). Akibat yang ditimbulkan dari adanya pandemi ini adalah berubahnya pola konsumsi dan pekerjaan sehingga menyebabkan perubahan terjadi pada pasar komoditas pangan yang salah satunya adalah ikan. Adanya ketidakpastian kondisi dan tingginya kekhawatiran terkait kesehatan ini terjadi di dalam kehidupan sosial masyarakat, tidak terkecuali pada masyarakat nelayan di Kota Bengkulu. Faktor COVID-19 ini diyakini mempengaruhi pendapatan nelayan. Mubarok dan Fajar (2020) menjelaskan dampak pandemi COVID-19 yang paling dirasakan nelayan ialah harga ikan yang mengalami penurunan drastis hingga mencapai $50 \%$. Hal ini tidak sebanding dengan usaha dan biaya operasional yang dikeluarkan nelayan saat melakukan penangkapan di laut.

Selain itu, saat ini pemerintah telah memberlakukan kebijakan mensosialisasikan dan menerapkan social distancing, physical distancing, work from home (WFH), dan pembatasan sosial berskala besar (PSBB) yang tercantum pada peraturan pemerintah RI No. 21 tahun 2020. Kebijakan tersebut dirasa sangat menyulitkan nelayan lokal dan industri perikanan tangkap dalam kegiatan memasarkan hasil tangkapan mereka. Akibatnya hasil tangkapan nelayan banyak mengalami kemunduran mutu dan bahkan membusuk. Tidak hanya itu, beberapa gudang penyimpanan ikan (cold storage) terjadi penumpukan bahan baku ikan atau over stock karena tidak dapat di suplai ke luar daerah sebagaimana biasanya (Djailani, 2020). COVID-19 sangat cepat menyebar dan belum diketahui sampai kapan berakhirnya wabah ini. Melihat perkembangan situasi saat ini, sangat diperlukan kajian tentang prediksi dampak COVID-19 terhadap kecenderungan (trend) perekonomian masyarakat pesisir sebelum pandemi COVID-19 dan saat masa pandemi COVID-19. Tujuan penelitian ini adalah memprediksi dampak COVID-19 terhadap pendapatan nelayan jaring insang (gill net fishermen) di Kota Bengkulu. 


\section{METODE PENELITIAN}

Penelitian ini merupakan penelitian survei. Dilakukan sebanyak 14 kali survei selama bulan April-Mei 2020. Lokasi penelitian ditentukan pada dua kecamatan yaitu Pelabuhan Pulau Baai (Kecamatan Kampung Melayu), Pantai Malabero dan Pantai Jakat (Kecamatan Teluk Segara), Kota Bengkulu Provinsi Bengkulu (Gambar 1). Teknik wawancara secara terstruktur dipilih sebagai teknik pengumpulan data primer. Penentuan responden penelitian dilakukan secara acak (random sampling) sebanyak 100 orang atau sekitar 10\% dari keseluruhan nelayan jaring insang yang terdapat di Kota Bengkulu. Data sekunder diperoleh dari laporan dinas terkait, baik yang terpublikasi maupun yang tidak terpublikasi serta literatur terkait lainnya. Data pendapatan nelayan diperoleh sebelum pandemi COVID-19 dan saat pandemi COVID-19 terjadi. Objek penelitian ini adalah nelayan jaring insang di Kota Bengkulu Provinsi Bengkulu. Bahan pendukung dalam pelaksanaan kegiatan pengumpulan di lapangan terdiri atas alat tulis, kuisioner penelitian, kamera digital dan alat pendukung lainnya.

Data pendapatan nelayan dan aktivitas nelayan jaring insang di Kota Bengkulu yang diperoleh selama proses pengumpulan data di lapangan selanjutnya diseleksi sesuai kebutuhan dan dianalisis. Penelitian ini menggunakan analisa sederhana untuk melihat tren (data time series) pendapatan nelayan Kota Bengkulu. Trend adalah keadaan data yang menaik atau menurun dari waktu ke waktu. Sedangkan data time series adalah nilai-nilai suatu variabel yang berurutan menurut waktu (misal: hari, minggu, bulan dan tahun). Dalam menduga pendapatan (ekonomi) biasanya ada fluktuasi/ variasi dari waktu ke waktu atau disebut dengan variasi time series. Variasi ini biasanya disebabkan oleh adanya faktor tren (trend factor), fluktuasi siklis (cyclical fluktuation), variasi musiman (seasonal variation), dan pengaruh random (irregular/random influences) (Yulianto, 2012).

Data pendapatan nelayan direkapitulasi selama 5 bulan terakhir sebelum pandemi COVID-19 dibuat (Oktober-Desember 2019 dan Januari-Februari 2020) dan data prediksi saat pandemi COVID19 (Prakiraan Maret-Desember 2020). Data time series dianalisis menggunakan metode kuadrat terkecil (least square method) yang mengikuti persamaan umum sebagai berikut:

$$
\hat{Y}=a+b x
$$

Keterangan:

$\mathrm{a}=$ Bilangan konstan

$\mathrm{b}=$ Koefisien kecondongan garis tren

$\mathrm{x}=$ Mewakili waktu (bulan)

Sedangkan untuk mencari nilai a dan b dari persamaan di atas, digunakan persamaan berikut:

$$
\begin{aligned}
& a=\frac{\sum y}{n} \mathrm{dan}, \\
& b=\frac{\sum x y}{\sum x 2}
\end{aligned}
$$

Secara keseluruhan lama waktu perhitungan prediksi pendapatan nelayan dapat digabungkan dengan asumsi-asumsi sebagai berikut:

1. Sampel diambil secara acak di Pelabuhan Pulau Baai, Pantai Malabero dan Pantai Jakat;

2. Fluktuasi kondisi alam dianggap sama, yaitu sebelum pandemi COVD-19 dan saat pandemi COVID 19 ;

3. Awal pandemi COVID-19 bulan Maret 2020;

4. Prediksi berakhirnya COVID bulan Desember 2020; dan

5. Kemampuan pewawancara saat pengambilan data lapang dianggap sama. 

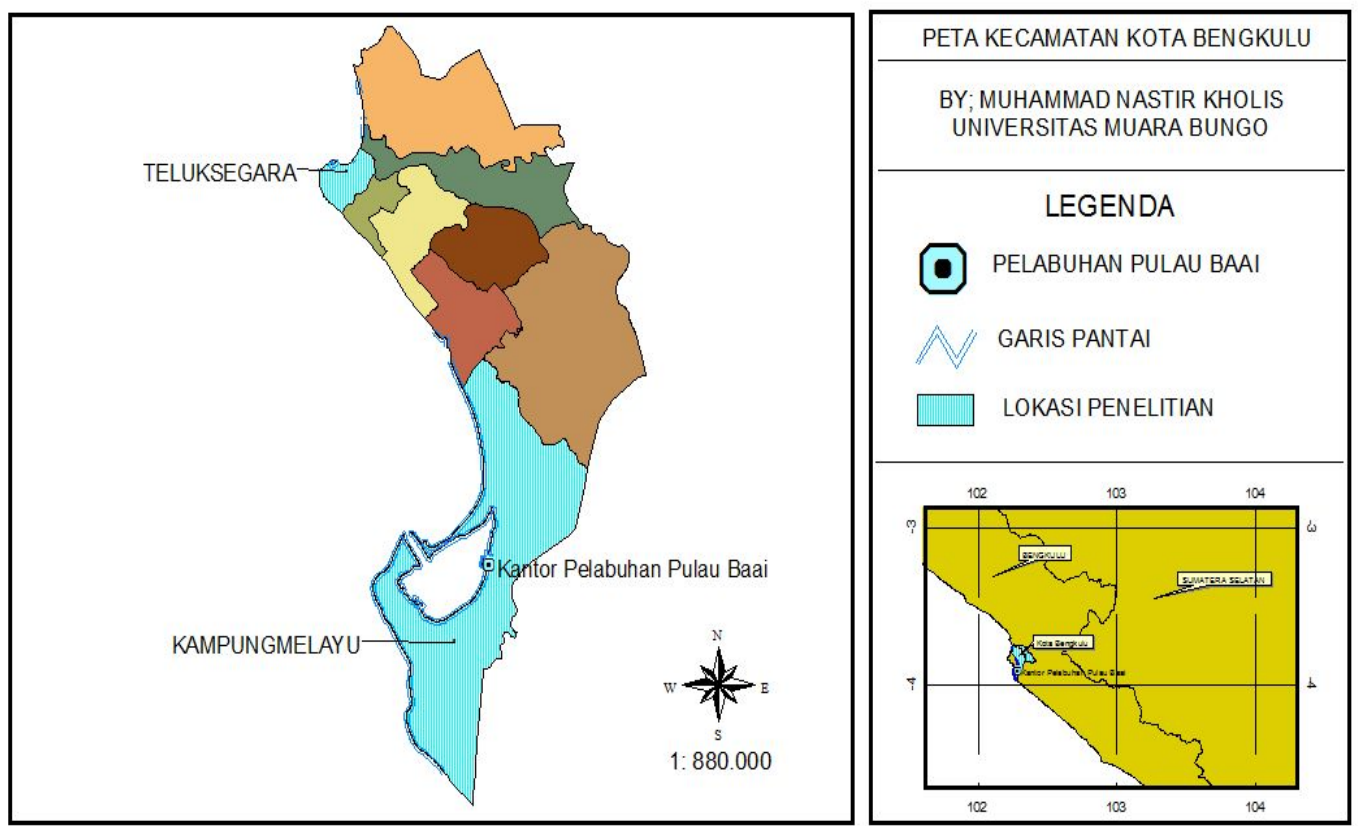

Gambar 1 Lokasi penelitian

\section{HASIL DAN PEMBAHASAN}

Mata pencaharian utama masyarakat pesisir Kota Bengkulu yaitu mencari ikan di laut atau lebih dikenal dengan sebutan nelayan. Nelayan Kota Bengkulu merupakan nelayan yang bekerja secara turun-temurun. Kondisi ekonomi masyarakat pesisir masih dikatakan tergolong miskin dengan alat tangkap yang digunakan masih tradisional dengan cakupan wilayah penangkapan yang masih dekat dengan garis pantai (Wahyudin, 2016) namun dari tingkat pendapatan sudah dapat memenuhi kebutuhan pokok dan kebutuhan lainnya seperti jajanan anak, transportasi dan komunikasi yang menjadi kebutuhan rutin dalam kehidupan keseharian (Zuriat, 2016).

Nelayan jaring insang di Kota Bengkulu terdiri dari dua kelompok, yaitu nelayan jaring ikan dan nelayan jaring lobster. Alat tangkap jaring insang ini digunakan oleh sebagian besar nelayan Kota Bengkulu dan masih dikategorikan sebagai nelayan tradisional. Spesifikasi jaring ikan yang digunakan di kota ini adalah berdimensi panjang 50 pieces atau sekitar 2.000 meter dan kedalaman sekitar $5 \mathrm{~m}$. Jaring ikan adalah jenis jaring permukaan, dengan perbandingan pelampung lebih banyak daripada pemberat. Sedangkan jaring lobster dikhususkan untuk menangkap lobster dan merupakan jenis jaring dasar, secara umum konstruksinya sama dengan jaring ikan. Perbedaan antara keduanya terletak pada panjang jaring dan komposisi pelampung dan pemberat. Jaring lobster memiliki panjang 30 pieces sekitar 1.200 meter dan jumlah pemberat lebih banyak daripada pelampung.

Nelayan menentukan daerah penangkapan ikan (fishing ground) menggunakan pengalaman (experience), kebiasaan (habit) dan perasan (feeling). Penentuan posisi kapal berpatokan kepada Gunung Kandis di sebelah Timur Daratan Kota Bengkulu. Daerah operasional alat tangkap ini berjarak antara 0-12 mil laut dengan karakteristik perairan bersubstrat pasir, berbatu dan terumbu karang. Lancang merupakan perahu yang digunakan sebagai armada penangkapan ikan oleh nelayan jaring insang Kota Bengkulu. Lancang adalah jenis kapal perahu yang diberi mesin berkekuatan 6,5 PK dengan kapasitas muatan 2 GT. Bentuk armada lancang ditunjukkan dalam (Gambar 2). 
Hasil tangkapan nelayan jaring insang Kota Bengkulu terdiri atas jenis ikan bersirip (fin fish) dan ikan non-bersirip (non-fin fish) seperti: ikan beledang (Trichiurus lepturus), gembolo (Rastrelliger sp.), kape-kape (Chaetodontidae sp.), belato (Alepes sp.), bawal putih (Pampus argenteus), bawal hitam (Parastromateus niger), tenggiri (Scomberomorini sp.), merah (Lutjanus campechanus), selengek (Alepes melanoptera), macho (Alepes sp.), gaguk (Hexanematichthys sagor), senangin (Eleutheronema tetradactylum), selar (Selar crumenophthalmus), lobster (Panulirus homarus), udang (Caridea sp.), kepiting (Brachyura sp.), pari (Batoidea sp.), lidah (Cynoglossidae sp.) dan lain-lain.

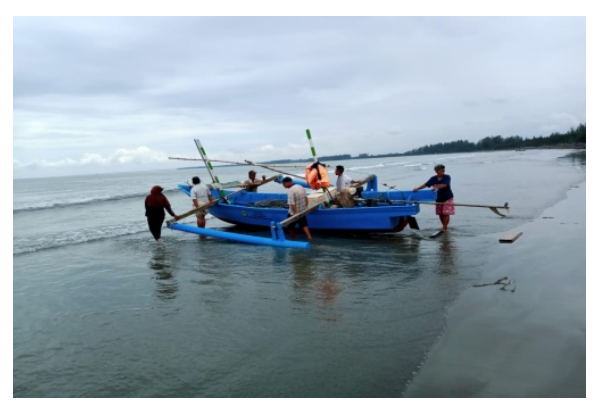

a

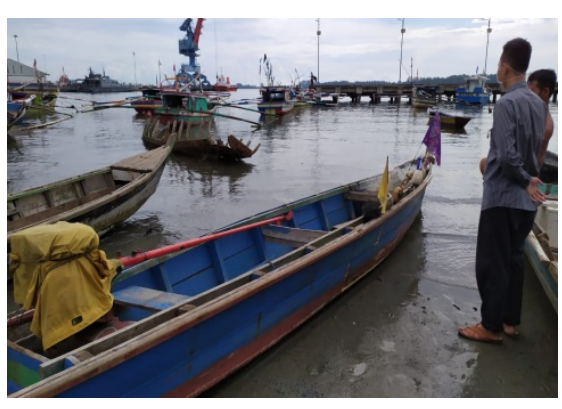

b

Gambar 2 (a) Kondisi nelayan Pantai Malabero dan Jakat; (b) Kondisi nelayan Pulau Baai

Pendapatan nelayan merupakan selisih antara penerimaan dengan biaya penangkapan yang benar-benar dikeluarkan baik per trip maupun per tahun. Hasil penelitian ini secara eksplisit memberikan gambaran pendapatan nelayan sebelum adanya pandemi COVID-19 terlihat stabil, namun dengan adanya pandemi ini menyebabkan terjadinya perubahan drastis terhadap tingkat pendapatan nelayan di lokasi penelitian. Menurut Kholis et al., (2017) pendapatan nelayan ditinjau dari banyaknya ikan hasil tangkapan setelah melakukan operasi penangkapan. Selanjutnya, Wismaningrum et al., (2013) mengungkapkan pendapatan merupakan nilai uang yang didapat dari hasil penjualan produksi ikan yang dipengaruhi oleh besarnya jumlah ikan hasil tangkapan dan harga yang terbentuk pada saat didaratkan.

Pendapatan usaha penangkapan ikan multigear diperoleh dari jumlah produksi setiap ikan dikalikan dengan harga rata-rata ikan. Menurut Rahim (2011) menjelaskan kesenjangan antara pemanfaatan dengan pengelolaan perikanan laut Indonesia merupakan kendala dalam meningkatkan pendapatan nelayan. Di mana kebijakan pengelolaan perikanan belum menjangkau kepentingan kelompok. Beberapa kasus menunjukkan bahwa nelayan skala kecil telah mengalami stagnasi produktivitas. Rendahnya produktivitas tersebut mengakibatkan pendapatan nelayan dalam jangka panjang tidak bisa mencukupi kebutuhan usaha dan rumah tangganya. Hasil prediksi terhadap ratarata pendapatan nelayan Kota Bengkulu sebelum pandemi dan saat pandemi COVID-19 (Oktober 2019Desember 2020) menunjukkan penurunan yang signifikan (Gambar 3). 


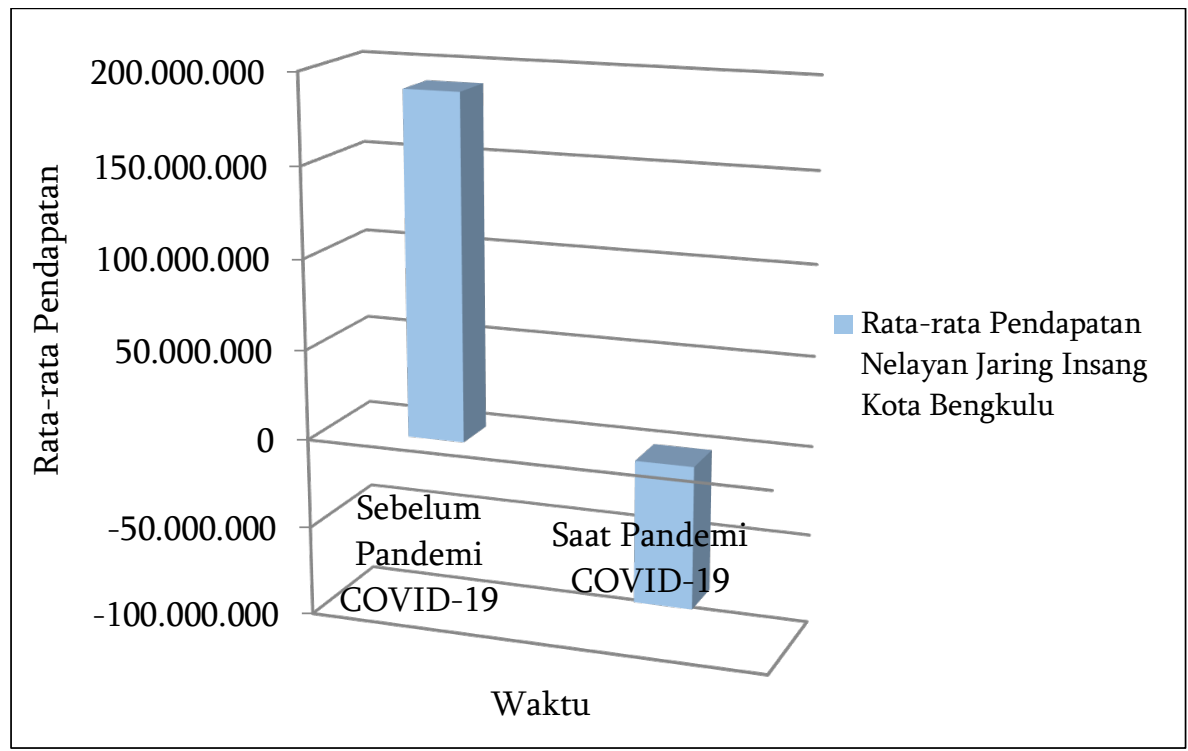

Gambar 3 Prediksi Rata-rata Pendapatan Nelayan Jaring Insang Kota Bengkulu Sebelum dan Saat Pandemi COVID-19 (Oktober 2019-Desember 2020)

Gambar 3 menunjukkan bahwa prediksi rata-rata pendapatan nelayan jaring insang Kota Bengkulu sebelum pandemi COVID-19 (Oktober 2019-Februari 2020) yaitu sebesar Rp189.937.142,86 sedangkan prediksi rata-rata pendapatan saat COVID-19 yaitu sebesar Rp-78.985.000,00. Jadi prediksi/prakiraan rata-rata pendapatan nelayan jaring insang sebelum COVID-19 dapat dikatakan masih stabil dan terkendali, tetapi saat pandemi COVID-19 (Maret 2020-Desember 2020) rata-rata pendapatan nelayan jaring insang menurun drastis (minus) sebesar Rp-78.985.000,00 dalam istilah ekonomi nelayan jaring insang diprediksi akan berhutang sampai prakiraan asumsi pandemi COVID19 berakhir bulan Desember 2020.

Seperti penelitian yang dilakukan oleh Indara (2017) yang menghitung pendapatan nelayan di Desa Bongo Kabupaten Gorontalo memiliki nilai rata-rata pendapatan sebesar Rp321.375.648,00 setiap tiga bulan. Sedangkan pendapatan berdasarkan rata-rata per nelayan yaitu sebesar Rp7.473.852,00. Lebih lanjut, penelitian yang dilakukan oleh Mubarok (2011) menemukan bahwa pendapatan masyarakat nelayan pandega di Kecamatan Kedung Kabupaten Jepara selama ini masih sangat tergantung dengan musim ikan. Pendapatan masyarakat nelayan tersebut di bedakan menjadi 2 (dua) musim yakni musim ramai dan musim sepi. Pada musim ramai nelayan cenderung mendapatkan pendapatan lebih, akan tetapi pengeluaran mereka cenderung boros. Sedangkan pada saat musim sepi, pendapatan menurun atau bahkan tidak ada. Menurut Wahyono et. al (2001); Kusnadi (2003); Ismail (2007) menyatakan bahwa pendapatan nelayan sangat berbeda dengan jenis usaha lainnya, seperti pedagang atau bahkan petani. Jika pedagang dapat mengkalkulasikan keuntungan yang diperolehnya setiap bulannya, begitu pula petani dapat memprediksi hasil panennya, maka tidak demikian dengan nelayan yang kegiatannya penuh dengan ketidakpastian (uncertainty) serta bersifat spekulatif dan fluktuatif.

Sebelum pandemi COVID-19 pendapatan nelayan jaring insang masih dapat dikatakan stabil, dari data survei bulan Oktober sampai November terjadi peningkatan pendapatan sebesar $20 \%$. Peningkatan diduga bulan November merupakan musim puncak penangkapan ikan di Kota Bengkulu dengan total pendapatan nelayan sebesar Rp321.740.000,00. Hal itu sependapat dengan (Direktorat Kredit, BPR dan UMKM, 2008) bahwa musim puncak hasil tangkapan ikan biasanya terjadi pada bulan Juli sampai Desember, selebihnya ialah waktu sepi ikan (paceklik). Sebelum pandemi COVID-19 pendapatan nelayan sudah mulai menurun sejak bulan Desember 2019 sampai Februari 2020 sebesar $11 \%$ sampai $-34 \%$. Artinya sebelum pandemi COVID-19 pendapatan nelayan telah berfluktuasi menurun sampai -34\% (Tabel 1). 
Saat pandemi COVID-19 diprediksi pendapatan nelayan jaring insang akan semakin berfluktuasi menurun drastis sampai bulan Juli 2020 sebesar -336\%, dan menjadi positif kembali pada bulan Agustus sampai Desember 2020. Artinya pendapatan nelayan jaring insang akan terus menurun hingga bulan Desember 2020 dan pada bulan Juli 2020 nelayan jaring insang diprediksi akan mulai berhutang dengan persentase sebesar -336\%. Bulan Juli 2020 juga diprediksi merupakan puncak penurunan pendapatan nelayan jaring insang Kota Bengkulu.

Tingginya persentase hutang pada bulan Juli 2020 disebabkan nelayan jaring insang yang tadinya tidak berhutang menjadi berhutang sehingga persentase meningkat drastis dari -77\% menjadi $-336 \%$. Pada bulan Agustus 2020 hutang nelayan jaring insang diprediksi akan terus bertambah, tetapi dengan persentase yang menurun. Bulan Agustus 2020 terjadi peningkatan hutang sebesar 142\%, diikuti September 2020 peningkatan hutang sebesar 59\%, Oktober 2020 peningkatan hutang 37\%, November 2020 peningkatan hutang sebesar 27\% dan Desember 2020 peningkatan hutang sebesar 21\%. Hal ini diduga merupakan dampak ketidakpastian kapan masa pandemi COVID-19 berakhir. Artinya nelayan jaring insang Kota Bengkulu akan terus berhutang sampai pandemi COVID-19 berakhir dengan jumlah persentase hutang berkurang per bulannya. Berkurangnya persentase hutang diprediksi karena ketidakmampuan nelayan mengembalikan hutang jika terus-menerus berhutang dengan persentase meningkat.

Gambar 4 menunjukkan bahwa persamaan tren pendapatan nelayan jaring insang Kota Bengkulu yaitu $\hat{Y}=1.899 .371-358562.86$ (x). Dengan persamaan tersebut dapat diprediksi tren pendapatan nelayan jaring insang menurun tajam hingga bulan Desember 2020. Berbeda hal kasus hasil tangkapan (produksi) ikan cakalang di PPS Bitung memiliki persamaan $\hat{Y}=19.590,64+8.772,22$ (x), yang artinya tren hasil tangkapan ikan cakalang yang didaratkan di PPS Bitung akan cenderung meningkat, sehingga kebutuhan pasokan bahan baku ikan cakalang untuk tiga tahun mendatang masih dapat terpenuhi (Saputra et al., 2014).

Nelayan jaring insang Kota Bengkulu memerlukan strategi untuk menghadapi prediksi masamasa sulit seperti saat ini, seperti strategi adaptasi yang dikemukakan oleh Nasrudin (2016) yang digunakan oleh nelayan untuk menghadapi ketidakpastian penghasilan adalah mengkombinasikan pekerjaan secara bergantian.

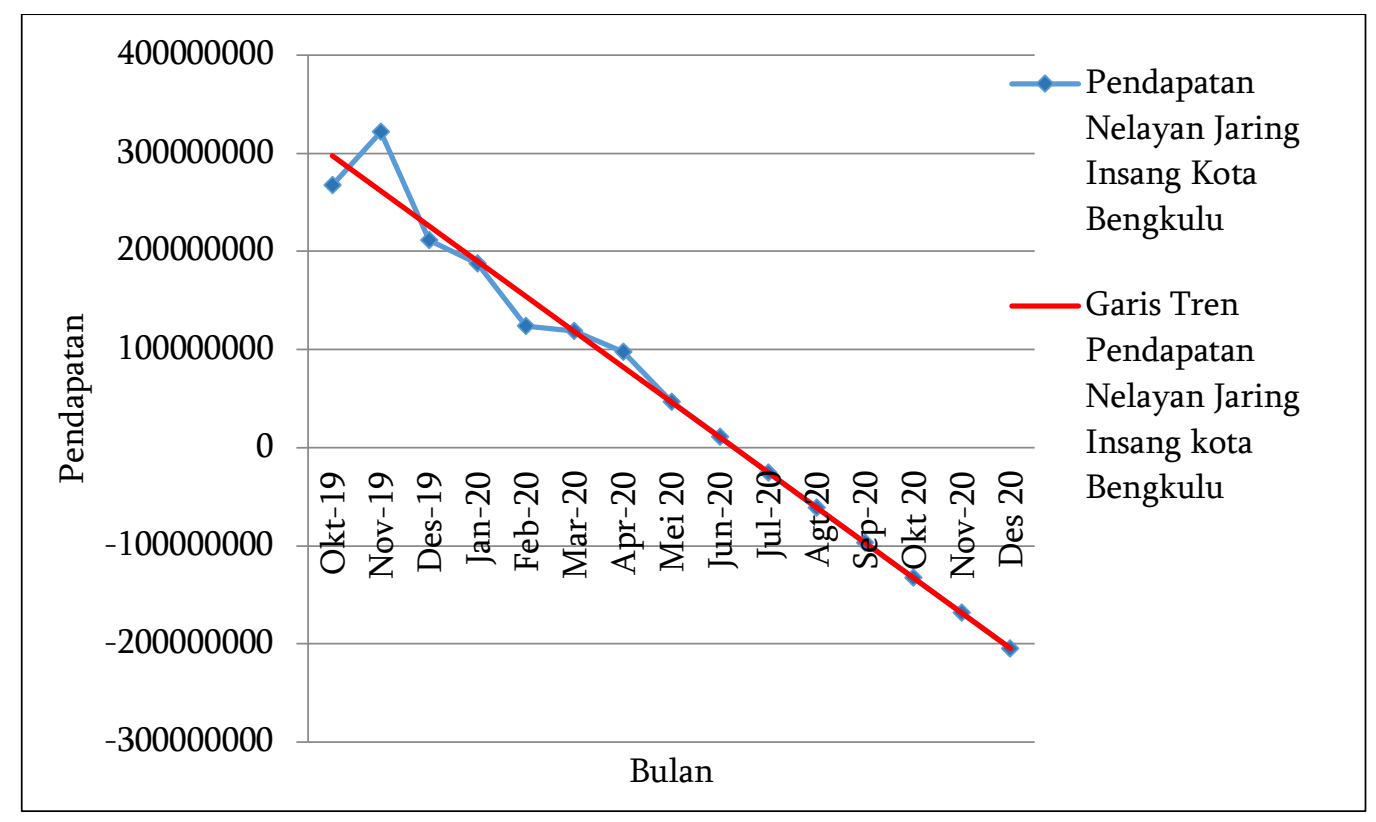

Gambar 4. Tren Prediksi Pendapatan Nelayan Jaring Insang Kota Bengkulu Sebelum dan Saat Pandemi COVID-19 (Oktober 2019-Desember 2020) 
Tabel 1 menjelaskan bahwa fluktuasi pendapatan nelayan jaring insang Kota Bengkulu sangat bervariatif. COVID-19 sangat jelas berpengaruh terhadap harga penjualan ikan sehingga pendapatan nelayan jaring insang di Kota Bengkulu menurun sangat tajam (drastis). Dampak COVID-19 tidak berpengaruh terhadap total hasil tangkapan nelayan, sehingga membuat nelayan sangat merugi akibat harga ikan menurun bahkan tidak bisa menjual hasil tangkapannya. Faktor lain yang mempengaruhi total hasil tangkapan nelayan jaring insang di Kota Bengkulu adalah faktor cuaca dan musim, karena kedua faktor ini sangat mempengaruhi lama melaut (trip) nelayan Kota Bengkulu yang bermuara pada total hasil tangkapan berkurang.

Hal ini senada dengan yang ditemukan oleh Rahim (2011) dalam penelitian mengenai fluktuasi pendapatan dari hasil tangkapan nelayan di wilayah pesisir pantai Sulawesi Selatan yang disebabkan oleh faktor musim, terutama saat musim paceklik yang biasanya ditandai dengan penurunan jumlah hasil tangkapan. Hal ini mengakibatkan fluktuasi harga sehingga berdampak pada penurunan pendapatan nelayan. Selanjutnya Rahim (2011) juga menjelaskan nelayan perahu motor di lokasi penelitiannya dipengaruhi secara positif oleh harga minyak tanah dan produktivitas serta secara negatif dipengaruhi oleh harga bensin, lama melaut, trip dan perbedaan fishing ground.

Tabel 1. Persentase prediksi fluktuasi pendapatan nelayan jaring insang Kota Bengkulu

\begin{tabular}{cccc}
\hline Bulan & $\begin{array}{c}\text { Total Pendapatan } \\
\text { Nelayan }(\mathrm{Rp})\end{array}$ & $\begin{array}{c}\text { Persentase } \\
(\%)\end{array}$ & Keterangan \\
\hline Okt-19 & 267660000 & $0 \%$ & - \\
Nov-19 & $321,740,000$ & $20 \%$ & Naik \\
Des-19 & $211,740,000$ & $-34 \%$ & Turun \\
Jan-20 & $187,950,000$ & $-11 \%$ & Turun \\
Feb-20 & $124,016,000$ & $-34 \%$ & Turun \\
Mar-20 & $119,154,000$ & $-4 \%$ & Turun \\
Apr-20 & $97,300,000$ & $-18 \%$ & Turun \\
Mei 20 & $46,512,000$ & $-52 \%$ & Turun \\
Jun-20 & $10,655,714$ & $-77 \%$ & Puncak Penurunan (Awal \\
Jul-20 & $-25,200,571$ & $-336 \%$ & Berhutang) \\
Agt 20 & $-61,056,857$ & $142 \%$ & Turun (Hutang Bertambah) \\
Sep-20 & $-96,913,143$ & $59 \%$ & Turun (Hutang Bertambah) \\
Okt 20 & $-132,769,429$ & $37 \%$ & Turun (Hutang Bertambah) \\
Nov-20 & $-168,625,714$ & $27 \%$ & Turun (Hutang Bertambah) \\
Des 20 & $-204,482,000$ & $21 \%$ & Turun (Hutang Bertambah) \\
\hline
\end{tabular}

Keterangan:

Maret-April = Awal Pandemi COVID-19

Mei-Desember $=$ Prediksi Pendapatan Nelayan

Kecenderungan penurunan pendapatan nelayan secara signifikan (fluktuative condition) di lokasi penelitian, maka diperlukan antisipasi baik oleh nelayan sendiri sebagai pelaku utama (prime mover) maupun oleh para pengambil kebijakan terkait. Solusi alternatif seyogyanya dipersiapkan berdasarkan pada hasil penelitian ini yang menggambarkan kondisi ekstrim (prediksi) sebagai dampak dari COVID-19 sedang dan akan terjadi pada beberapa bulan ke depan terhadap nelayan jaring insang di Kota Bengkulu.

Sebagai pekerjaan yang bergantung kepada sumberdaya alam, pekerjaan sebagai nelayan merupakan pekerjaan yang paling sensitif terhadap adanya perubahan kebijakan namun juga dipengaruhi oleh faktor yang tidak dapat dikendalikan oleh manusia seperti faktor alam misalnya musim. Faktor tak terkendali (uncontrolable factors) ini juga menyebabkan kerentananan terhadap ekonomi nelayan yang sifatnya sangat berfluktuasi. Penelitian yang dilakukan oleh Zuriat (2016) di 
Aceh Barat Daya menunjukkan bahwa pemerintah daerah telah mencoba berbagai program untuk dilaksanakan, termasuk pemanfaatan potensi sumberdaya perikanan yang bertujuan untuk meningkatkan pendapatan dan kesejahteraan masyarakat nelayan. Seperti penggunaan sarana penangkapan ikan berupa kapal motor, perahu motor dan bagan apung.

Adanya ketidakpastian kondisi pandemi COVID-19 saat ini maka kiranya diperlukan strategi bagi nelayan untuk dapat bertahan hidup dan dapat keluar dari musibah wabah ini. Selain intervensi bantuan sosial dari pemerintah baik daerah maupun provinsi bahkan pusat, strategi-strategi bertahan hidup nelayan tentu saja perlu ditingkatkan. Beberapa penelitian yang telah dilakukan menunjukkan bagaimana nelayan dapat bertahan hidup dari adanya ketidakpastian kondisi lingkungannya seperti Nasrudin (2016) yang menemukan berbagai cara nelayan untuk memenuhi kebutuhan hidupnya, seperti nelayan di Pantai Angin-angin Wedung yaitu dengan memanfaatkan kelembagaan setempat yang masih cukup kuat seperti gotong royong, ikatan kekerabatan, hubungan ketetanggaan dan rasa solidaritas yang tinggi di antara sesama nelayan. Hal itu telah melahirkan sikap tenggang rasa yang muncul dalam bentuk saling berbagi di antara nelayan. Hubungan sosial ini merupakan salah satu mekanisme strategi bertahan hidup pada kelompok masyarakat nelayan miskin.

Penelitian yang dilakukan Wahyudin (2016) menemukan nelayan tradisional patorani berkembang sejak tahun 1980, dengan munculnya moderninasi di kalangan nelayan berupa pemakaian mesin pada perahu, hal itu mendorong nelayan patorani untuk meningkatkan produktivitas hasil tangkapan dan mulailah melaut pada daerah yang lebih jauh dari garis pantai. Dengan beralihnya ke peralatan modern, nelayan patorani tidak hanya berfokus pada kebutuhan rumah tangga saja akan tetapi lebih meningkatkan produktivitas hasil tangkapannya guna meningkatkan taraf hidup ekonomi keluarganya, sehingga diharapkan nelayan patorani keluar dari garis kemiskinan.

Menurut Tain (2013) terdapat 15 faktor dominan penyebab kemiskinan rumah tangga nelayan kecil yaitu faktor: kelembagaan yang merugikan nelayan kecil, program yang tidak memihak nelayan kecil, pandangan hidup yang berorientasi akhirat saja, keterbatasan sumberdaya, ketidaksesuaian alat tangkap, rendahnya investasi, terikat utang, perilaku boros, keterbatasan musim penangkapan, kerusakan ekosistem, penyerobotan wilayah tangkap, lemahnya penegakan hukum, kompetisi untuk mengungguli nelayan lain, penggunaan alat/bahan terlarang serta perilaku penangkapan.

\section{KESIMPULAN DAN SARAN}

Penelitian ini dapat disimpulkan bahwa pandemi COVID-19 sangat berdampak terhadap pendapatan nelayan jaring insang di Kota Bengkulu akibat turunnya harga penjualan ikan. Nelayan jaring insang diprediksi akan berhutang mulai bulan Juli 2020 sampai bulan Desember 2020, dengan prediksi puncak penurunan pendapatan tertinggi dan awal berhutang pada bulan Juli 2020 dengan persentase sebesar $-336 \%$. Oleh karena itu, diperlukan penanganan lebih lanjut dari para pengambil kebijakan terkait (related stakeholder) dalam memberikan kepastian terhadap keberlanjutan usaha perikanan jaring insang di Kota Bengkulu ke depan.

\section{UCAPAN TERIMA KASIH}

Ucapan terima kasih disampaikan kepada tim peneliti dari Universitas Muara Bungo, Universitas Bina Insan dan Universitas Muhammadiyah Bengkulu. Penelitian ini terlaksana berkat mitra program KOTAKU Oversight Consultant (OC2) Bengkulu dengan Fakultas Ekonomi Universitas Muhammadiyah Bengkulu selaku lembaga pelaksana penelitian ini. 


\section{DAFTAR PUSTAKA}

Azamfirei R. (2020). The 2019 Novel Coronavirus: A Crown Jewel of Pandemics? The Journal of Critical Care Medicine 6 (1): p3-4.

Data Statistik Kementerian Kelautan dan Perikanan (KKP). (2016). Data Statistik Jumlah Jenis Alat Tangkap di Kota Bengkulu. Diakses pada: Https://yhudaya.blogspot.com/2019/02/penggunaantrawl-di-kota-bengkulu_8.html?m=1. [Diunduh 07 Mei 2020].

Direktorat Kredit, BPR dan UMKM. 2008. Pola Pembiayaan Usaha Kecil (PPUK)-Penangkapan Ikan Pelagis dengan Alat Tangkap Gill net. Jakarta (ID): Bank Indonesia.

Direktorat Jendral Penguatan Daya Saing Produk Kelautan dan Perikanan (Dirjen PDSPKP). Kementerian Kelautan dan Perikanan (KKP). 2018. Profil Potensi Usaha dan Peluang Investasi Kelautan dan Perikanan Provinsi Bengkulu. 92hal.

Djailani O. 2020. Dampak Covid-19 Terhadap Sektor Perikanan Maluku Utara. Diakses pada: Https://rri.co.id/ternate/ekonomi/818717/dampak-covid-19-terhadap-sektor-perikananmaluku-utara. [Diunduh 05 Mei 2020].

Erwina, Y., Kurnia, R., Yonvitner. 2015. Status Keberlanjutan Sumber Daya Perikanan di Perairan Bengkulu. Jurnal Sosek KP 10 (1): 21-34.

Indara, S. R., Bempah, I., \& Boekoesoe, Y. 2017. Faktor-faktor yang Mempengaruhi Pendapatan Nelayan Tangkap di Desa Bongo Kecamatan Batudaa Pantai Kabupaten Gorontalo. AGRINESIA: Jurnal Ilmiah Agribisnis, 2(1), 91-97.

Ismail, Z. 2007. Faktor-faktor yang mempengaruhi Penghasilan dan Pola Konsumsi Nelayan, Dampak Kerusakan Lingkungan Pesisir terhadap Kondisi Sosial Ekonomi Nelayan. Jakarta.

Kholis, M. N., Wahju, R. I., \& Mustaruddin, M. 2017. Keragaan Aspek Teknis Unit Teknologi Penangkapan Ikan Kurau di Pambang Pesisir Kabupaten Bengkalis Provinsi Riau. Jurnal Teknologi Perikanan dan Kelautan, 8(1). hal 67-79.

Kusnadi. 2003. Akar Kemiskinan Nelayan. LKIS. Yogyakarta.

Masydzulhak. 2005. Pengelolaan Sumberdaya Pesisir di Kota Bengkulu. Jurnal Penelitian UNIB XI (1): 21-28.

Mubarok F., dan Fajar J. 2020. Dampak COVID-19 Terhadap Harga Ikan Tangkapan Nelayan Turun Drastis. Diakses pada: Https://www.mongabay.co.id/2020/04/02/dampak-covid-19-hargatangkapan-ikan-nelayan-turun-drastis/. [Diunduh 05 Mei 2020].

Mubarok, A. F. 2011. Analisis Pendapatan dan Strategi Pemenuhan Kebutuhan Ekonomi Masyarakat Nelayan di Kabupaten Jepara (Doctoral dissertation, Universitas Negeri Semarang).

Mulyasari, G. 2015. Prospek Pengembangan Usaha Perikanan Tangkap di Kota Bengkulu. Jurnal Social Economic of Agriculture 4 (2): 1-7.

Nasrudin, T. 2016. Strategi Bertahan Hidup Nelayan Angin-angin Kecamatan Wedung Kabupaten Demak. [Skripsi]. UIN Sunan Kalijaga. Yogyakarta. 38 Hlm.

Rahim, A. 2017. Analisis pendapatan usaha tangkap nelayan dan faktor-faktor yang mempengaruhinya di wilayah pesisir pantai Sulawesi Selatan. Jurnal Sosial Ekonomi Kelautan dan Perikanan, 6(2), 235-247.

Ridha, A. 2017. Analisis faktor-faktor yang mempengaruhi pendapatan nelayan di Kecamatan Idi Rayeuk. Jurnal Samudra Ekonomi dan Bisnis 8 (1): 646-652. 
Saputra, A., Sompie, M. S., \& Manoppo, L. 2014. Analisis tren hasil tangkapan ikan cakalang (Katsuwonus pelamis) dengan alat tangkap purse seine dan pole and line (Studi kasus di Pelabuhan Perikanan Samudera Bitung). Jurnal Ilmu dan Teknologi Perikanan Tangkap, 1(6): 204-208.

Suhana 2020. Dampak COVID-19 Terhadap Pelaku Perikanan Lokal. Diakses pada: Https://suhana.web.id/2020/04/17/dampak-covid-19-terhadap-pelaku-perikanan-lokal/. [Diunduh 06 Mei 2020].

Tain, A. 2013. Penyebab kemiskinan rumah tangga nelayan di wilayah tangkap lebih Jawa Timur. Jurnal Humanity, 7(1): 1-10.

Wahyono, A., \& Antariksa, I. G. P. M., Imron., R. Indrawasih, dan Sudiyono. 2001. Pemberdayaan Masyarakat Nelayan, Media Pressindo, Jogjakarta.

Wahyudin, N. 2016. Dinamika Kehidupan Sosial Ekonomi Masyarakat Nelayan Patorani di Kecamatan Galesong Kabupaten Takalar 1890-2014. Jurnal Pattingalloang, 3(4): 98-104.

Wismaningrum KEP, Ismail, Fitri ADP. 2013. Analisis Finansial Usaha Penangkapan One Day Fishing dengan Alat Tangkap Multigear di Pelabuhan Perikanan Pantai (PPP) Tawang Kabupaten Kendal. JFRUMT, 2(3): 263-272.

Yulianto, MA. 2012. Analisa Time Series untuk Perikanan. Diakses pada: https://digensia.wordpress.com/2012/08/24/analisa-time-series/ . [Diunduh 09 Mei 2020].

Zuriat, Z. 2016. Analisis Pendapatan Nelayan Pada Kapal Motor 5-10 GT di Kabupaten Aceh Barat Daya. Jurnal Perikanan Tropis, 3(1). 